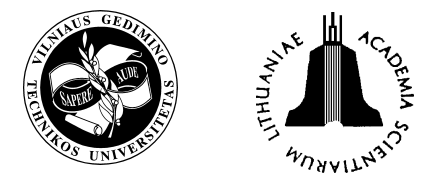

\title{
THE IMPACT OF EXTERIOR FINISH VAPOUR RESISTANCE ON THE MOISTURE STATE OF BUILDING WALLS
}

\author{
Jolanta Šadauskienė, Edmundas Monstvilas, Vytautas Stankevičius \\ Institute of Architecture and Construction at Kaunas University of Technology, \\ Tunelio g. 60, LT-44405 Kaunas, Lithuania \\ E-mail: jolanta.sadauskiene@asi.lt
}

Received 8 September 2006; accepted 15 February 2007

\begin{abstract}
At present, when the building walls covered with a painted thin render are insulated by the mineral wool slabs from outside, the defects caused by the condensed moisture accumulated in the envelopes become more and more frequent. Water vapour permeability of the exterior finish (ie the paint), if compared with the water vapour permeability of the mineral wool slab, is rather small. That is why the paint coating may become the barrier for the water vapour diffusion and thus create favourable conditions for moisture accumulation in the exterior layers of the envelope during cold seasons. As a rule, to eliminate the defects, the exterior surface is repainted on the former paint coating because the render is thin and mechanically easily damaged. Repainting the thin render surface causes the following: 1) an increase of the exterior coating's vapour resistance; 2) a growth of the condensation intensity in the envelope exterior layers during the of moisture accumulation; 3 ) a decrease of the durability of the render-paint system. The restrictions for the envelope exterior layer $s_{d}$ have already been recommended to employ in the European Union. Since moisture accumulation inside the wall is determined by the local climate, it is important to find out whether the recommendations concerning the given $s_{d}$ value might be applied for the exterior layers of the building walls in Lithuania. To find it out, the calculations of the envelope state and laboratory experiments have been carried out. The paper aims at the analysis of the impact of vapour permeability and its properties in the exterior layers of the wall on the envelope moisture state. It has been determined that the increase of the $s_{d}$ value is disproportionate to the number of the paint layers or the thickness of the paint coating. It has also been determined that the increase of the $s_{d}$ value forms the pre-conditions for the increased moisture amount under service conditions caused by water diffusion and condensation. The experiments revealed that, under Lithuanian climatic conditions, in the exploited building walls the $s_{d}$ value of the exterior layer of the thin render should make $s_{d}<0,5 \mathrm{~m}$ and $s_{d}<0,6 \mathrm{~m}$ in the paint coating.
\end{abstract}

Keywords: painted thin render, finish system, water vapour permeability, water vapour resistance factor, water vapour diffusion, equivalent air layer thickness, moisture state.

\section{Introduction}

A building envelope insulation is popular all over the world. At present, with the use of new, effective materials and products for finishing the buildings, the defects caused by the condensed moisture accumulated in the envelopes become more frequent. This problem is especially relevant to the design of the exterior walls insulated with mineral wool slabs from outside that are finished with the painted thin render. Such constructions are multi-layered and the moisture parameters in the separate layers are varying. It should be stressed that, in comparison with the mineral wool's water permeability, water vapour permeability in the exterior layer (ie the paint) is rather insignificant; that's why the paint coating may become a barrier to water vapour diffusion and create preconditions for moisture accumulation in the envelope during cold seasons [1]. With the cyclical recurrence of the freezing-warming process, when the envelope is moist, an intensive destruction of the exterior finish may take place.

In most cases, to eliminate the defects the exterior surface is repainted. However, the former coating is preserved because the render is thin and mechanically easily damaged. As Y. Shala claims [2], the restoration of the exterior insulating system which requires a new paint coating should be carried out every 10-15 years. If the average building service period is 70 years [3], then, during the entire building service, the exterior walls may be repainted 8 or more times (one complete paint coating of the building facades 
consists of two layers). Therefore each repainting causes the following:

- an increase of the exterior coating's vapour resistance;

- a growth of the condensation in the envelope during moisture accumulation;

- a durability decrease of the rendering-paint system.

As R. Miniotaite proved by experiments $[4,5]$, resistance to climatic effects in the coatings made of poliacrilites, silicon solutions obtained with the use of organic solvents or of silicon dispersions depends on vapour permeability.

This permeability is characterised by several moisture parameters, such as relative vapour resistance factor $\mu$ or air layer thickness $s_{d} \mu$ equivalent to the building material's water vapour permeability is the ratio of the coefficient of outdoor air water vapour permeability and the coating's vapour permeability. The ratio is used to determine the moisture characteristics of homogenic materials. The material's relative vapour resistance $\mu$ shows how many times the vapour resistance value of the coating made of this material is higher than that of an immovable air layer of the similar thickness. The higher the quantity $\mu$, the poorer the properties of the material's water vapour permeability. Water vapour permeability of the paint coatings is described by the index $s_{d}$. It is the thickness of the air layer (m) equivalent to water vapour diffusion that shows the coating's resistance to water vapour diffusion, ie the drying of the wall. The higher the $s_{d}$ value of the paint, the poorer the drying conditions for the materials that are under the coating. It means that water vapour may start condensing under the paint pellicle and thus to increase the moisture of the envelope and to decrease its durability.

The designers of the multi-layer building constructions should consider the layer composition in such a way that the layers' vapour resistance increased toward the exterior of the wall, ie the exterior coating should be the most permeable to the vapour stream $[6,7]$. This factor has already been considered in the European Standard Project pr EN 13500 [8]. The vapour transfer coefficient of the finish for a day should not be higher than $40 \mathrm{~g} /\left(\mathrm{m}^{2} \cdot \mathrm{d}\right)$. According to DIN 18550 [9], moisture will not accumulate in the envelope if in the exterior layers $w \cdot s_{d} \leq 0,2 \mathrm{~kg} /\left(\mathrm{mh}^{0,5}\right)$ where the surface water absorption is $w \leq 0,5 \mathrm{~kg} /\left(\mathrm{m}^{2} \mathrm{~h}^{0,5}\right)$ and $s_{d} \leq 2 \mathrm{~m}$. Today the recommended moisture parameters are: $w \leq 0,1 \mathrm{~kg} /\left(\mathrm{m}^{2} \mathrm{~h}^{0,5}\right)$ and $s_{d} \leq 1 \mathrm{~m}[10]$. All the mentioned restrictions for the envelope coating's $s_{d}$ are applied in the EU.

Moisture inside the wall is determined by the local climate. In Lithuania, the climate is colder than in Western Europe. Here the average temperature in January and February is often about $-10{ }^{\circ} \mathrm{C}$ and lower. Therefore the abovementioned $s_{d}$ value restrictions cannot be applied for the wall's exterior layers of the buildings in Lithuania. Neither can the given $s_{d}$ value restriction [8-10] be recommended for the buildings' exterior walls during the design or in the initial period of the building service: the Standard Project does not consider the alteration of the $s_{d}$ values of the wall's exterior finish during the building service. Therefore it is important to determine the possible boundaries of the vapour resistance alteration in the walls of the buildings in Lithuania.

\section{Method of investigation}

The Standards EN ISO 13788 [11] and STR 2.05.01:2005 [12] provide the calculation method that allows the determination of the annual moisture amount balance and the greatest amount of accumulated moisture $\left(\mathrm{kg} / \mathrm{m}^{2}\right)$ caused by the condensation inside the envelopes. In order to calculate the vapour resistance of the wall's exterior finish it is necessary to find out the values of the coating's water vapour permeability. The majority of the producers do not indicate the water vapour permeability parameters of the building materials used for finish, since they are included into the list of the indices not obligatory to be declared. Moreover, various scientific sources define different values of moisture quantities [12,13]. It is also important to point out that no investigations have been carried out to determine the dependence of the coating's vapour resistance on the number of the coated paint layers during service and therefore the following questions arise: how much does this dependence alter with different paints used; whether the vapour resistance increases in all sorts of paint and what effect does it have on the moisture state of the entire envelope. Therefore, in order to prognosticate the envelope moisture state, it is urgent to determine the values of vapour permeability in various sorts of paint by taking into consideration the number and thickness of the paint coatings.

\subsection{Determination of vapour resistance in the double-layer coating-base system by the number of paint coatings}

Having analysed the producer-indicated properties of the paint's water vapour permeability, the authors selected the most popular paints in Lithuania, ie acrylic, silicate, poluretanic and silicon ones. The moisture characteristics of these paints indicated by the producers [14-19] are in Table 1.

For determining the moisture parameters for each sort of paint, 12 samples of the system paint-thin render have been treated. In each group, three samples were coated with the paint layers of different thickness obtained by the following number of the paint layers coated on the sample's base: $2,4,6,8$. Three samples were left unpainted, just 
covered with a thin render. All the samples were of $100 \mathrm{~mm}$ in diameter and of about $10 \mathrm{~mm}$ thickness (Fig 1).

Water vapour permeability was determined in the environment of $23^{\circ} \mathrm{C}$, as it is required by the LST EN ISO 12572:2001 Standard [20]. The difference of the water vapour pressures on the different sides of the sample was worked out and the density of the water vapour stream passing through the sample was measured. Vapour resistance $Z,\left(\mathrm{~m}^{2} \cdot \mathrm{s} \cdot \mathrm{Pa} / \mathrm{kg}\right)$ was calculated in the following way:

$$
Z=\frac{p_{1, s a t}-p_{2}}{q}-\frac{d_{o}}{\delta_{p}^{a i r}},
$$

where: $p_{1, \text { sat }}$ - points to the partial pressure of the satu-rated water vapour, $\mathrm{Pa}, p_{2}$ - the partial pressure of water vapour above the sample, $\mathrm{Pa}, d_{o}$ - the thickness of the air layer from the water surface in the cup to the bottom of the sample after the latest weighing, $\mathrm{m} ; \delta_{p}^{\text {air }}$ - the coefficient of water vapour diffusion in the air equal to $2 \cdot 10^{-10} \mathrm{~kg} /(\mathrm{m} \cdot \mathrm{s} \cdot \mathrm{Pa})$.

In the double-layer system of the coating (ie paint), vapour resistance was calculated as follows:

$$
Z=Z_{p}-Z_{b}
$$

where: $Z_{b}$ - vapour resistance of the thin render sample, $\left[\mathrm{m}^{2} \cdot \mathrm{s} \cdot \mathrm{Pa} / \mathrm{kg}\right] ; Z_{p}-$ vapour resistance of the sample representing the paint-thin render system, $\left[\mathrm{m}^{2} \cdot \mathrm{s} \cdot \mathrm{Pa} / \mathrm{kg}\right]$.

Accordingly, $s_{d}$ was obtained:

$$
s_{d}=Z \cdot \delta_{p}^{a i r}
$$

\subsection{Determination of vapour resistance in the double- layer coating-base by the paint coating thickness}

When the thin render is covered with several paint coatings without paint utilisation control, it is difficult to determine the real thickness of the coating. Therefore, with the use of the method of the water vapour permeability determination described in Part 2.1, an additional experiment was carried out during which, in the preparation of the samples, the paint utilisation was controlled and the thickness of the paint coating determined.

For this experiment the paint sorts presented in Table 1 were selected and they were coated on the thin render samples ( $100 \mathrm{~mm}$ in diameter; $\approx 10 \mathrm{~mm}$ thick). The amount of the paints to be covered on the base and, accordingly, the obtained thickness of the paint was calculated due to remains of the dry material. The calculation results are in Table 2. The thin render samples were covered with adequate paint coatings whose thickness was $0,08,0,16$ and $0,24 \mathrm{~mm}$.
Table. 1 Paint properties and their dependence on the sort of paint

\begin{tabular}{|l|c|c|c|}
\hline Sorts of paint & $s_{d}, \mathrm{~m}$ & $\begin{array}{c}\text { Moisture } \\
\text { resistance }\end{array}$ & Durability \\
\hline Acrylic & $0,3-1$ & ++ & - \\
\hline Silicate & $0,06-0,3$ & + & + \\
\hline Poluretanic & $0,2-1,2$ & - & - \\
\hline Silicon & $0,12-0,3$ & ++ & ++ \\
\hline++- good; + normal; - no data. \\
\hline
\end{tabular}

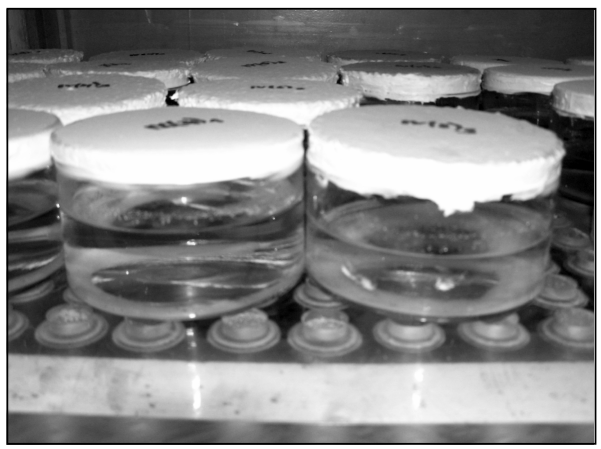

Fig 1. The samples used for determining the water vapour permeability in the paint-thin rendering system

\subsection{The moisture state of the wall}

With the exact $s_{d}$ values of the paints it is possible to forecast the envelope's moisture state during service, at the same time estimating vapour resistances of the paint coatings. Such calculations will help determine whether without additional moisturing the wall's exterior finish does not prevent the moisture transfer from inside and whether moisture does not accumulate inside the wall. They will also help finding out what effect the increase of the finish vapour resistance makes on the wall's moisture and to estimate the critical values of vapour resistance in the wall's exterior finish.

The standards [11-12] provide the calculation method that allows to determine the annual moisture amount balance and the greatest amount of accumulated moisture $\left(\mathrm{kg} / \mathrm{m}^{2}\right)$ caused by the condensation occuring inside the envelopes. These methods may also provide the comparison of the moisture state of different constructions. Since the transfer of water vapour is rather slow and durable the values of the average monthly temperature and relative air moisture should be taken for calculation. Such precision is satisfactory for determining of the conditions under which water vapour condensation is possible as well as of its place and amounts of condensation and evaporation (ie drying).

On the basis of the discussed standard method, the calculations of the moisture state have been carried out (Fig 2) for the envelope. The physical parameters of the layers are presented in Table 3 . They confirm the stationary conditions for the Kaunas city during January when the characteristics of water vapour permeability in the exterior walls finish differ. 
The microclimatic parameters in the interior premises were: $20{ }^{\circ} \mathrm{C}$ and $60 \%$ relative air humidity. In all calculations equal indoor and outdoor air temperature and relative air humidity were accepted.

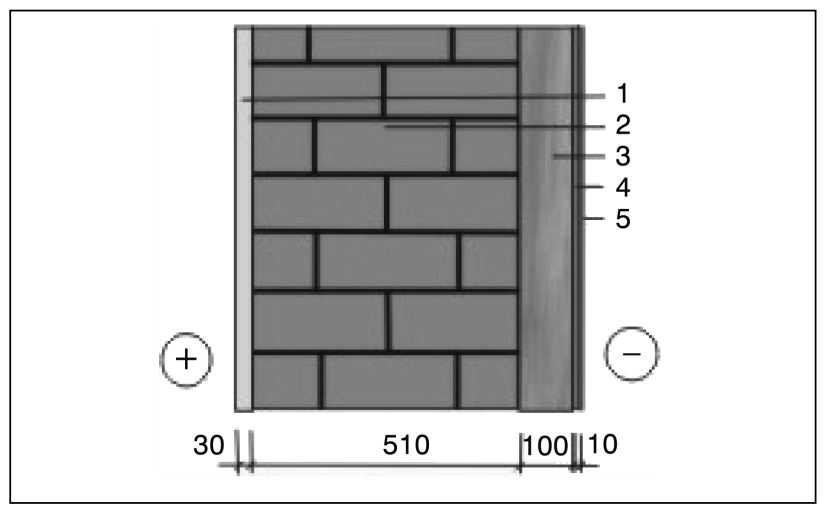

Fig 2. Wall construction: 1 - mineral render from inside; 2 - ceramic brick wall; 3 - mineral wool; 4 - thin mineral render; 5 - paint

\section{Results and discussion}

\subsection{Dependence of the exterior finish vapour resistance on its thickness and the number of coatings}

The results of investigation are presented in Tables 4-6. With the help of the value of the thin render's vapour resistance $Z_{b}$ and the value of the thin render-paint coating system's vapour resistance $Z_{p}$ the paint coating's vapour resistance $Z$ (according to formula (2)) and the thickness of the air layer $s_{d}$ equivalent to the building material's water vapour permeability (according to formula (3)) were calculated.

The results of determining the air layer thickness $s_{d}$ show that, with an increase of the number of paint coatings or the thickness of the coating, the paint coatings $s_{d}$ also increases. The degree of the increase of the $s_{d}$ value depends on the sort of paint, ie the pigment, the polarity of film formation and the binder.

Table 2. Estimation of the paint amount necessary for determining the adequate paint coating's thickness

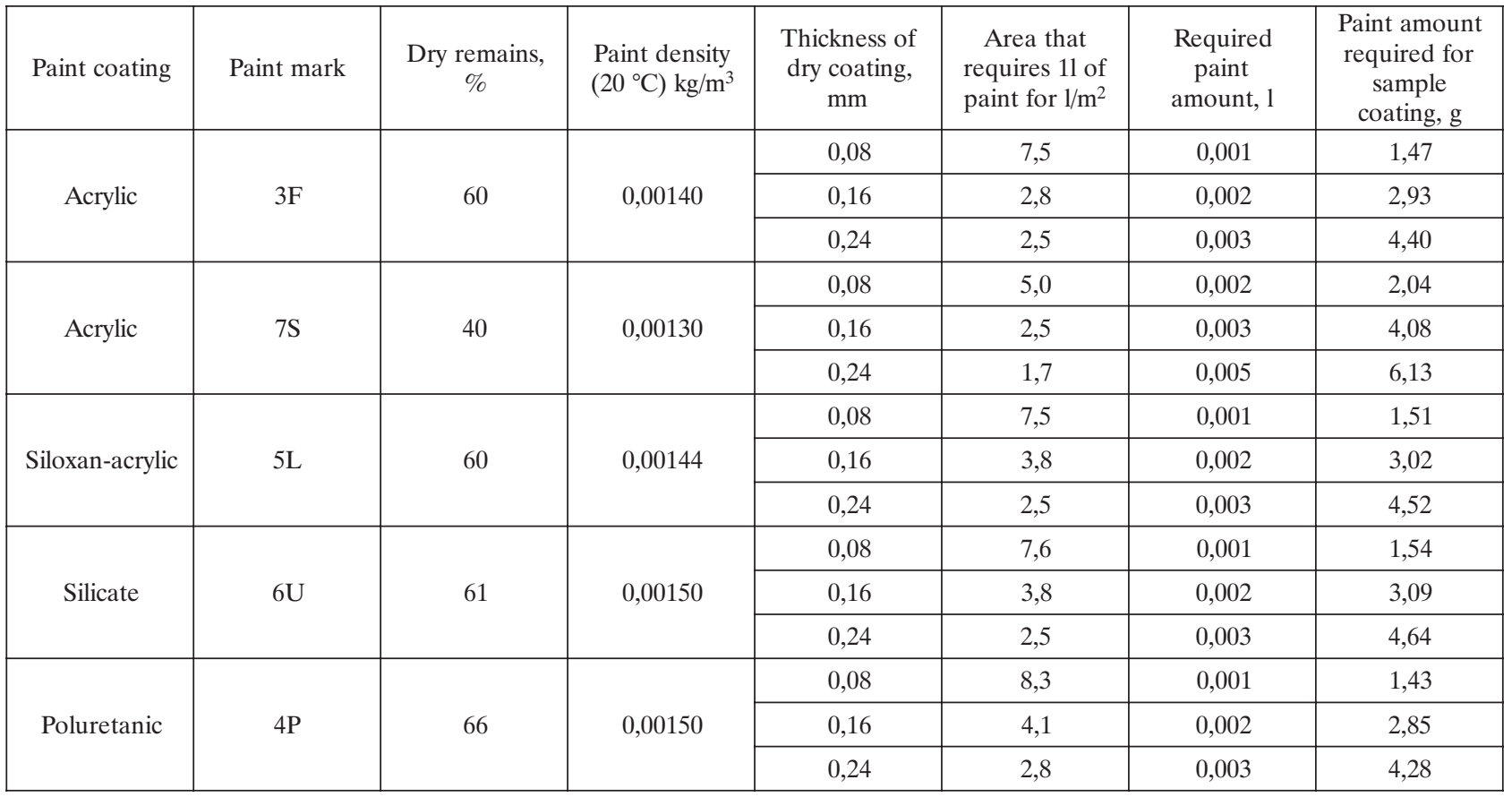

Table 3. Physical parameters of the envelope layers

\begin{tabular}{|c|c|c|c|c|c|}
\hline $\begin{array}{c}\text { Type of the } \\
\text { envelope layers }\end{array}$ & $\begin{array}{l}\text { Thickness of the } \\
\text { building material's } \\
\text { layer } d, \mathrm{~mm}\end{array}$ & Density $\rho, \mathrm{kg} / \mathrm{m}^{3}$ & $\begin{array}{c}\text { Building material's } \\
\text { thermal conductivity } \\
\text { coefficient } \lambda \text {, } \\
\mathrm{W} /(\mathrm{m} \cdot \mathrm{K})\end{array}$ & $\begin{array}{c}\text { Relative water } \\
\text { vapour resistance } \mu\end{array}$ & $s_{d}, \mathrm{~m}$ \\
\hline 2. Brick masonry & 510 & 1400 & 0,64 & 10 & 5,1 \\
\hline 3. Mineral wool & 100 & 80 & 0,04 & 1 & 0,1 \\
\hline 5. Paint & 0.1 & - & 1 & - & $\begin{array}{l}\text { According to paint } \\
\text { coating number and } \\
\text { thickness }\end{array}$ \\
\hline
\end{tabular}


J. Šadauskiene et al. / ÜKIO TECHNOLOGINIS IR EKONOMINIS VYSTYMAS-2007, Vol XIII, No 1, 73-82

Table 4. Values of vapour permeability of the mineral thin render-paint coating system by considering the number of coatings

\begin{tabular}{|c|c|c|c|c|c|}
\hline Paint mark & Paint coating & $\begin{array}{c}\text { Number of paint } \\
\text { layers }\end{array}$ & $\begin{array}{c}\text { Relative vapour } \\
\text { resistance } \mu\end{array}$ & $\begin{array}{c}\text { Vapour resistance } \\
Z_{p},(\mathrm{~m} \cdot \mathrm{h} \cdot \mathrm{Pa}) / \mathrm{mg}\end{array}$ & $s_{d}, \mathrm{~m}$ \\
\hline \multirow{4}{*}{$1 \mathrm{E}$} & \multirow{4}{*}{ Silicate 1} & 2 & 0,014 & 0,730 & 0,444 \\
\hline & & 4 & 0,012 & 0,856 & 0,521 \\
\hline & & 6 & 0,010 & 0,862 & 0,524 \\
\hline & & 8 & 0,010 & 0,942 & 0,572 \\
\hline \multirow{3}{*}{$2 \mathrm{SF}$} & \multirow{3}{*}{ Siloxan } & 2 & 0,024 & 0,447 & 0,272 \\
\hline & & 6 & 0,021 & 0,498 & 0,302 \\
\hline & & 8 & 0,020 & 0,549 & 0,334 \\
\hline \multirow{3}{*}{$3 \mathrm{~F}$} & \multirow{3}{*}{ Acrylic 1} & 2 & 0,010 & 0,926 & 0,563 \\
\hline & & 4 & 0,008 & 1,369 & 0,832 \\
\hline & & 6 & 0,008 & 1,369 & 0,904 \\
\hline \multirow{2}{*}{$4 \mathrm{P}$} & \multirow{2}{*}{ Poluretanic } & 6 & 0,019 & 0,511 & 0,310 \\
\hline & & 8 & 0,016 & 0,526 & 0,319 \\
\hline \multirow{4}{*}{$5 \mathrm{~L}$} & \multirow{4}{*}{ Siloxan-acrylic } & 2 & 0,023 & 0,441 & 0,268 \\
\hline & & 4 & 0,020 & 0,500 & 0,304 \\
\hline & & 6 & 0,018 & 0,562 & 0,341 \\
\hline & & 8 & 0,016 & 0,632 & 0,384 \\
\hline \multirow{3}{*}{$6 \mathrm{U}$} & \multirow{3}{*}{ Silicate 2} & 2 & 0,027 & 0,344 & 0,209 \\
\hline & & 4 & 0,025 & 0,376 & 0,228 \\
\hline & & 6 & 0,024 & 0,397 & 0,241 \\
\hline
\end{tabular}

Table 5. Values of the water vapour permeability parameters of the mineral thin render

\begin{tabular}{|c|c|c|c|}
\hline $\begin{array}{c}\text { Vapour permeability coefficient } \\
\delta_{p}, \mathrm{~kg} /(\mathrm{m} \cdot \mathrm{s} \cdot \mathrm{Pa})\end{array}$ & $\begin{array}{c}\text { Vapour resistance } Z_{b}, \\
(\mathrm{~m} \cdot \mathrm{s} \cdot \mathrm{Pa}) / \mathrm{kg}\end{array}$ & Relative vapour resistance $\mu$ & $s_{d}, \mathrm{~m}$ \\
\hline 0,036 & 0,178 & 16,2 & 0,157 \\
\hline
\end{tabular}

Table 6. Values of vapour permeability of the mineral thin render-paint coating system when considering the paint coatings thickness

\begin{tabular}{|c|c|c|c|c|c|}
\hline Paint mark & Paint coating & $\begin{array}{l}\text { Thickness of paint } \\
\text { layers, mm }\end{array}$ & $\begin{array}{c}\text { Vapour resistance } \\
Z_{p},(\mathrm{~m} \cdot \mathrm{h} \cdot \mathrm{Pa}) / \mathrm{mg}\end{array}$ & $\begin{array}{c}\text { Relative vapour } \\
\text { resistance } \mu\end{array}$ & $s_{d}, \mathrm{~m}$ \\
\hline \multirow{3}{*}{$3 \mathrm{~F}$} & Acrylic 1 & 0,08 & 1,210 & 71,0 & 0,733 \\
\hline & & 0,16 & 1,280 & 88,4 & 0,780 \\
\hline & & 0,24 & 1,400 & 95,1 & 0,851 \\
\hline \multirow{3}{*}{$4 \mathrm{P}$} & Poluretanic & 0,08 & 0,381 & 27,6 & 0,232 \\
\hline & & 0,16 & 0,446 & 28,9 & 0,268 \\
\hline & & 0,24 & 0,453 & 36,5 & 0,275 \\
\hline \multirow{3}{*}{$5 \mathrm{~L}$} & Siloxan-acrylic & 0,08 & 0,430 & 26,0 & 0,264 \\
\hline & & 0,16 & 0,470 & 26,7 & 0,288 \\
\hline & & 0,24 & 0,542 & 31,7 & 0,329 \\
\hline \multirow{3}{*}{$6 \mathrm{U}$} & Silicate 2 & 0,08 & 0,348 & 22,1 & 0,212 \\
\hline & & 0,16 & 0,362 & 23,3 & 0,220 \\
\hline & & 0,24 & 0,466 & 24,4 & 0,283 \\
\hline \multirow{3}{*}{$7 \mathrm{~S}$} & Acrylic 2 & 0,08 & 1,337 & 62,0 & 0,753 \\
\hline & & 0,16 & 1,423 & 84,4 & 0,812 \\
\hline & & 0,24 & 1,540 & 89,3 & 0,864 \\
\hline
\end{tabular}




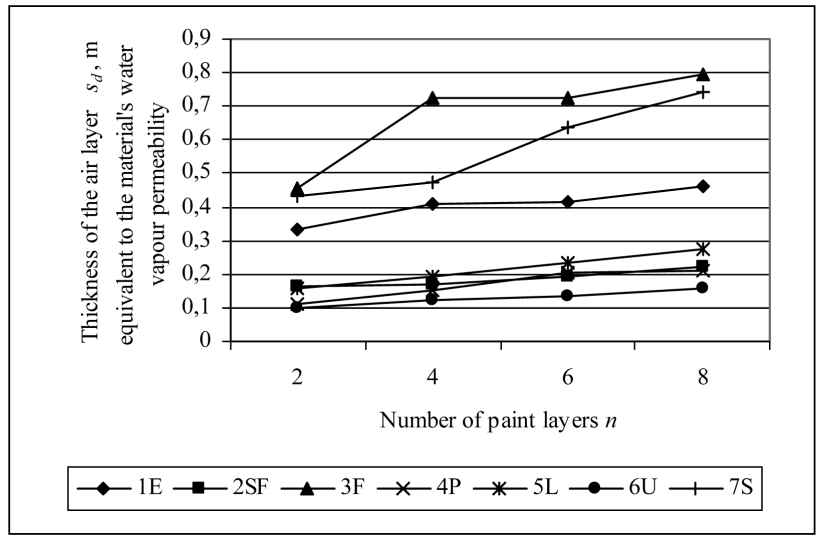

Fig 3. Dependence of the air layer thickness $s_{d}$ equivalent to the building material's water vapour permeability on the number of the paint layers

Figs 3, Fig 4 illustrate well that the first two coverings of the paint coatings indicate the main vapour characteristics of the paint sort. In deeper coatings they are more distinct. When the number of the coatings grows from 2 to 8 , $s_{d}$ of the silicate paints (1E; 6U) increases by 1,5 times; $s_{d}$ of the siloxan paints (2SF; $5 \mathrm{~L})$ increases $1,4-1,7$ times and $s_{d}$ of the poluretanic (4P) and acrylic (3F; $\left.7 \mathrm{~S}\right)$ paints - up to 1,8 times. It shows that the increase of the $s_{d}$ value is not proportional to the number of the paint coatings, ie the thickness of the whole paint coating. The $s_{d}$ value of the acrylic paint ( $3 \mathrm{~F}$ and $7 \mathrm{~S}$ ) is considerably higher than those of other sorts of paint examined.

In order to estimate the finish coating's water vapour transfer coefficient $\left(W=40 \mathrm{~g} / \mathrm{m}^{2} \cdot \mathrm{d}\right)$ in the insulation system introduced in the European Standard Project where the mineral wool slabs are presented as an insulating material, the authors recalculated the coefficient into the value of relative vapour resistance, the result making $\mu=44$. Then $s_{d}$ of the exterior $1 \mathrm{~cm}$ thick coating makes $s_{d}=0,44 \mathrm{~m}$. The thickness of the paint coatings calculated, it is possible to recalculate the $\mu$ value recommended by the European Standard into the $s_{d}$ value of an adequate paint coating's thickness. Thus, according to the prEN 13500:2002, the $s_{d}$ of the paint coating of $0,08 \mathrm{~mm}$ thickness should be $s_{d}<$ $0,0035 \mathrm{~m}$; of $0,16 \mathrm{~mm}$ thickness $s_{d}<0,007 \mathrm{~m}$ and of $0,24 \mathrm{~mm}$ thickness $s_{d}<0,01 \mathrm{~m}$. Figs 3,4 demonstrate that the paint coatings of all sorts do not meet the requirements concerning the limiting values of vapour permeability of the exterior coatings presented in the European Standard Project. It encouraged the authors to carry out the calculations of the envelope moisture (Fig 2) and estimate the real (ie obtained during the investigation) vapour resistances of the paint coating under the climatic conditions characteristic of Lithuania. With the application of the discussed calculation method, it is possible to determine the limiting values of vapour resistance of the exterior coatings used in the buildings exploited in Lithuania.

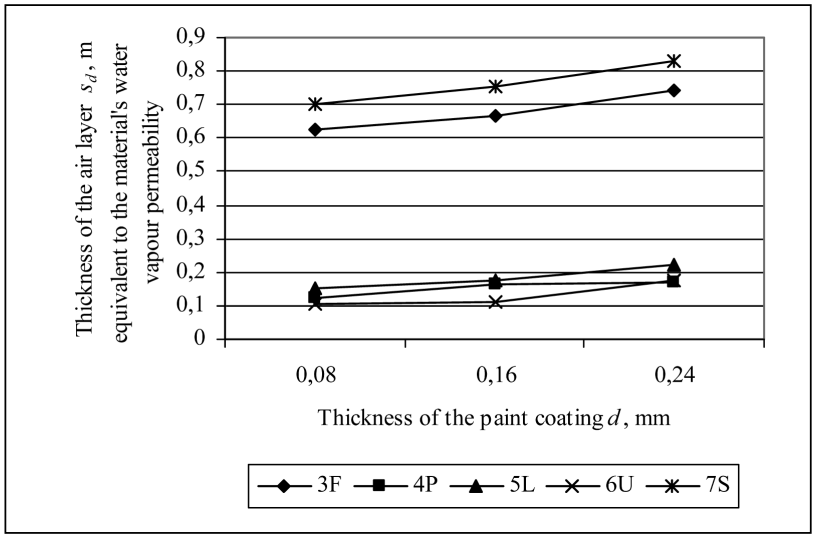

Fig 4. Dependence of the air layer thickness $s_{d}$ equivalent to the building material's water vapour permeability on the thickness of the paint layer

\subsection{The impact of the thin renders vapour resistance on the moisture state of the entire wall}

The results of the experiments carried out in the Laboratory of Thermal Physics at the Institute of Architecture and Construction (Lithuania) demonstrate that, if compared to the mineral wool slab's water vapour permeability coefficient $\delta_{p} \approx 0,5 \mathrm{mg} /(\mathrm{m} \cdot \mathrm{h} \cdot \mathrm{Pa})$, the water vapour permeability coefficients of the tested render samples are 10 times lower [21]. It allows for the conclusion that the drying conditions of the mineral wool will be complicated. Table 7 presents the values of the parameters describing water vapour permeability of several sorts of thin render finish [12]. The calculation of the moisture state of the envelope presented in Fig 2 was carried out with the use of the standard method discussed in Part 2.3.

The calculation results (Fig 5) demonstrate that moisture distribution in the envelope's cross-section in case of any thin render finish with various values of vapour parameters is similar. The zone of condensation is possible to appear between the thin render finish and the mineral wool slabs.

The dynamics of moisture accumulation and drying in the envelope was determined by the same calculation method (Fig 2). The condensation is most expected to occur between the mineral wool layer and the thin render in the course of the year. Fig 6 displays that when $s_{d}$ thickness of the air layer equivalent to the building material's water vapour permeability in the thin render finish makes less than $0,5 \mathrm{~m}$, moisture does not accumulate in the envelope. However, with the increase of the $s_{d}$ value of the exterior thin render finish, the possibility arises for the accumulation of the greater moisture amount in the insulation layer. When the amount of moisture increases, the probability for its drying out during the warm seasons becomes smaller.

Table 5 presented the $s_{d}$ value of the mineral thin render investigated in the given paper, which is $0,157 \mathrm{~m}$. It is lower 
than the critical $s_{d}$ value of the exterior coating $(0,5 \mathrm{~m})$. Therefore, when analysing the water vapour transfer in the entire structure of the insulated wall, it should be considered that, with the absence of an additional moisturing of the insulated material, the mineral render with the $s_{d}$ value 0,157 will be satisfactory to guarantee the normal moisture state of the exterior walls of the buildings exploited in Lithuania.

Table 7. Parameters describing water vapour permeability of the thin render layers

\begin{tabular}{|l|c|c|c|}
\hline \multicolumn{1}{|c|}{ Type of render } & $\mu$ & Thickness $d, \mathrm{~mm}$ & $\mu \times d=s_{d}, \mathrm{~m}$ \\
\hline Polymeric render of low permeability & 300 & 10 & 3 \\
\hline Polymeric render, permeable & 100 & 10 & 1 \\
\hline Polymeric render of high permeability & 50 & 10 & 0,5 \\
\hline Mineral render & 6 & 10 & 0,06 \\
\hline
\end{tabular}

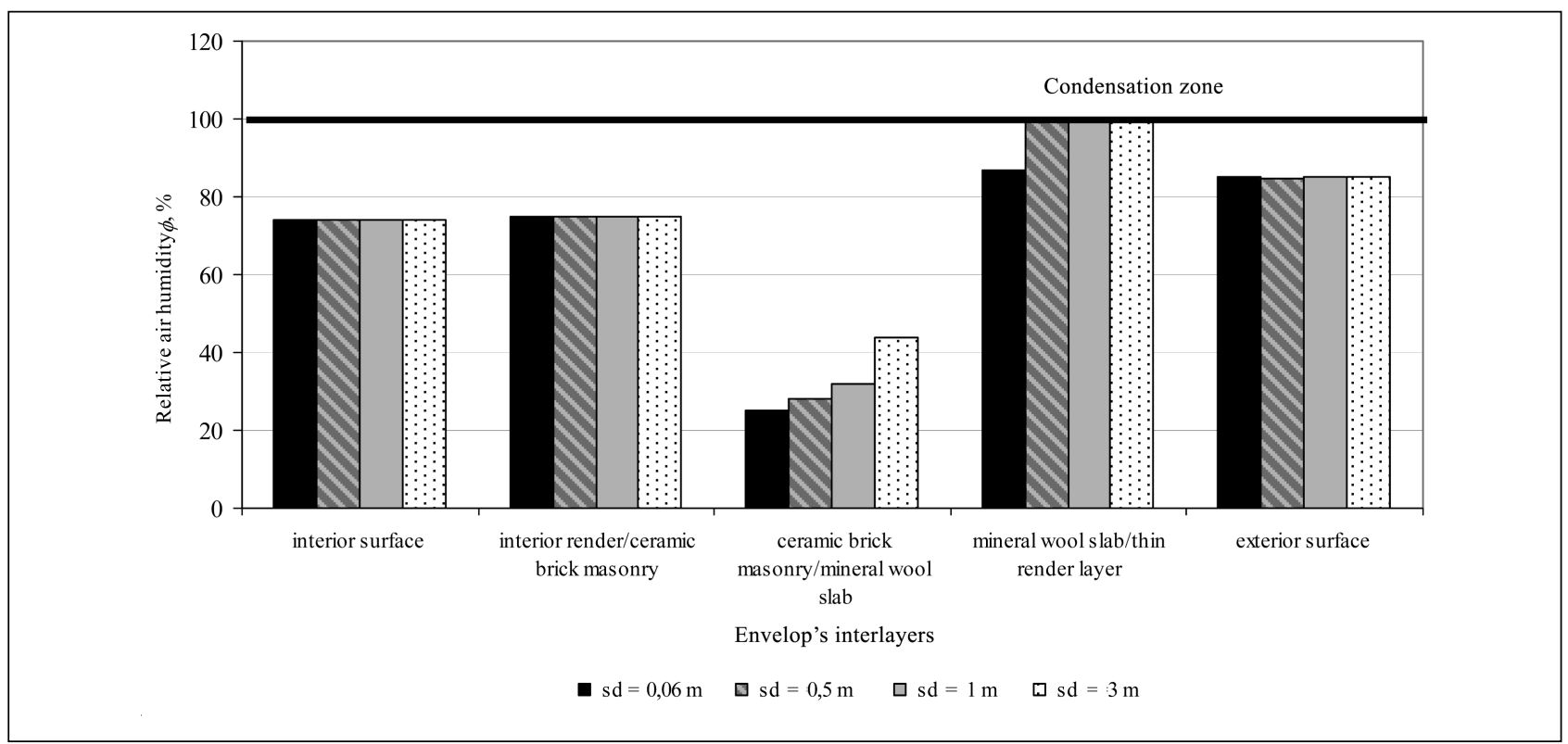

Fig 5. The impact of the thin render finish with different moisture characteristics on the moisture state of the insulated envelope

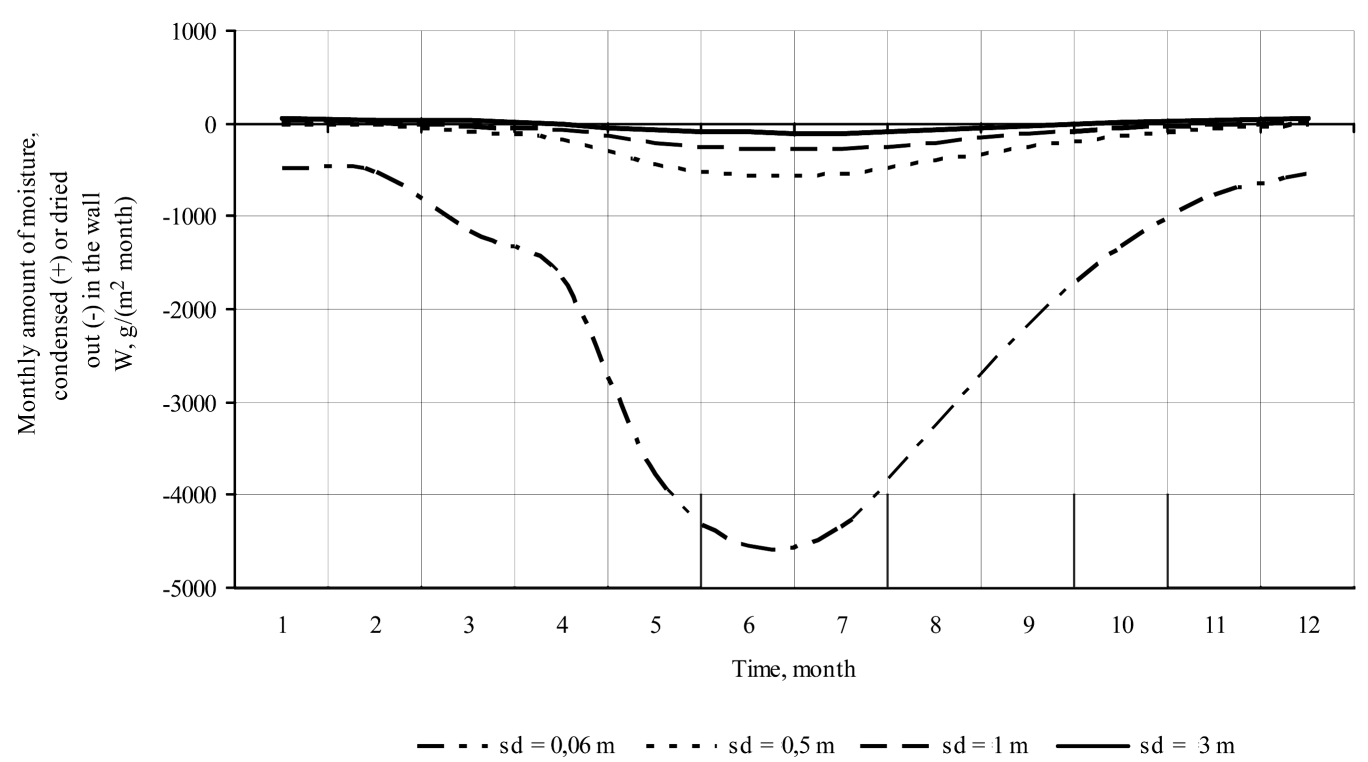

Fig 6. Annual dynamics of moisture alteration in the wall in its possible zone of condensation when the thickness of the air layer equivalent to the material's water vapour permeability $s_{d}$ varies 
3.3. The impact of the coating's vapour resistance on the moisture state of the entire wall

Part 3.2 presented the analysis of the mineral thin render under the climatic conditions typical of Lithuania, thereby concluding that the mineral thin render will not make any difficulty for the movement of water vapour and thus will not damage the moisture state of the entire wall. Yet the question arises whether the wall moisture state will change when the vapour resistance of the discussed exterior layer becomes higher, ie when the thin render finish is painted from outside.

The $s_{d}$ values (Table 1) of various paint sorts presented by the producers fluctuate within the interval from $0,02 \mathrm{~m}$ to $1 \mathrm{~m}$. Therefore, according to the STR 2.01.05:2005 [12], the calculations were made to show whether with the absence of additional moisturing the wall's exterior finish would not affect the moisture migration from inside and whether the moisture would not accumulate inside the wall. The calculations demonstrate that, after the painting of the facade of the building insulated from outside with the mineral wool slabs that were finished with thin render, two planes of condensation would appear in the envelope, ie between the mineral wool slab and thin mineral render and between thin mineral render and the paint coating (Fig 7).

The dynamics of the annual moisture accumulation and drying in the envelope (ie between the thin mineral render

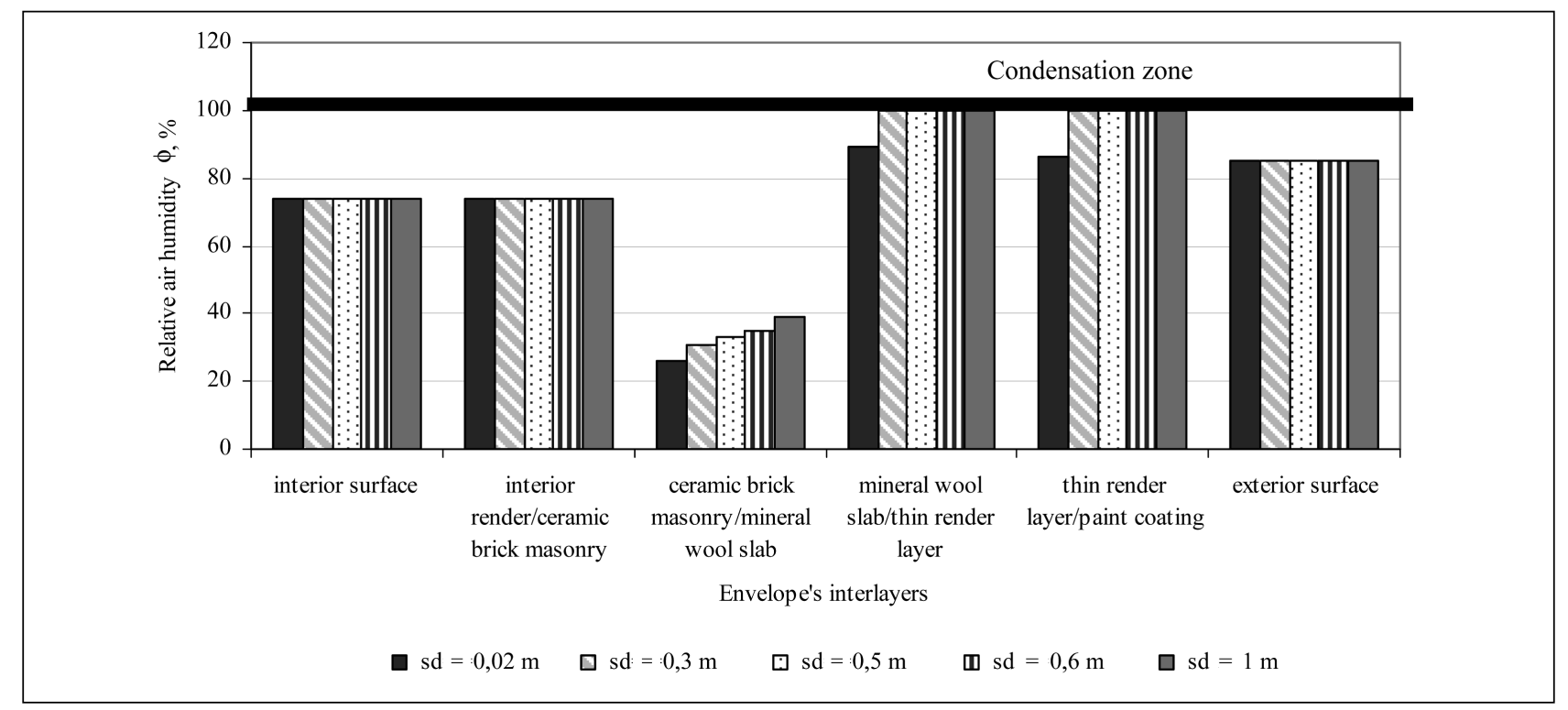

Fig 7. Dependence of the paint coating with various moisture characteristics on the moisture state of the insulated wall

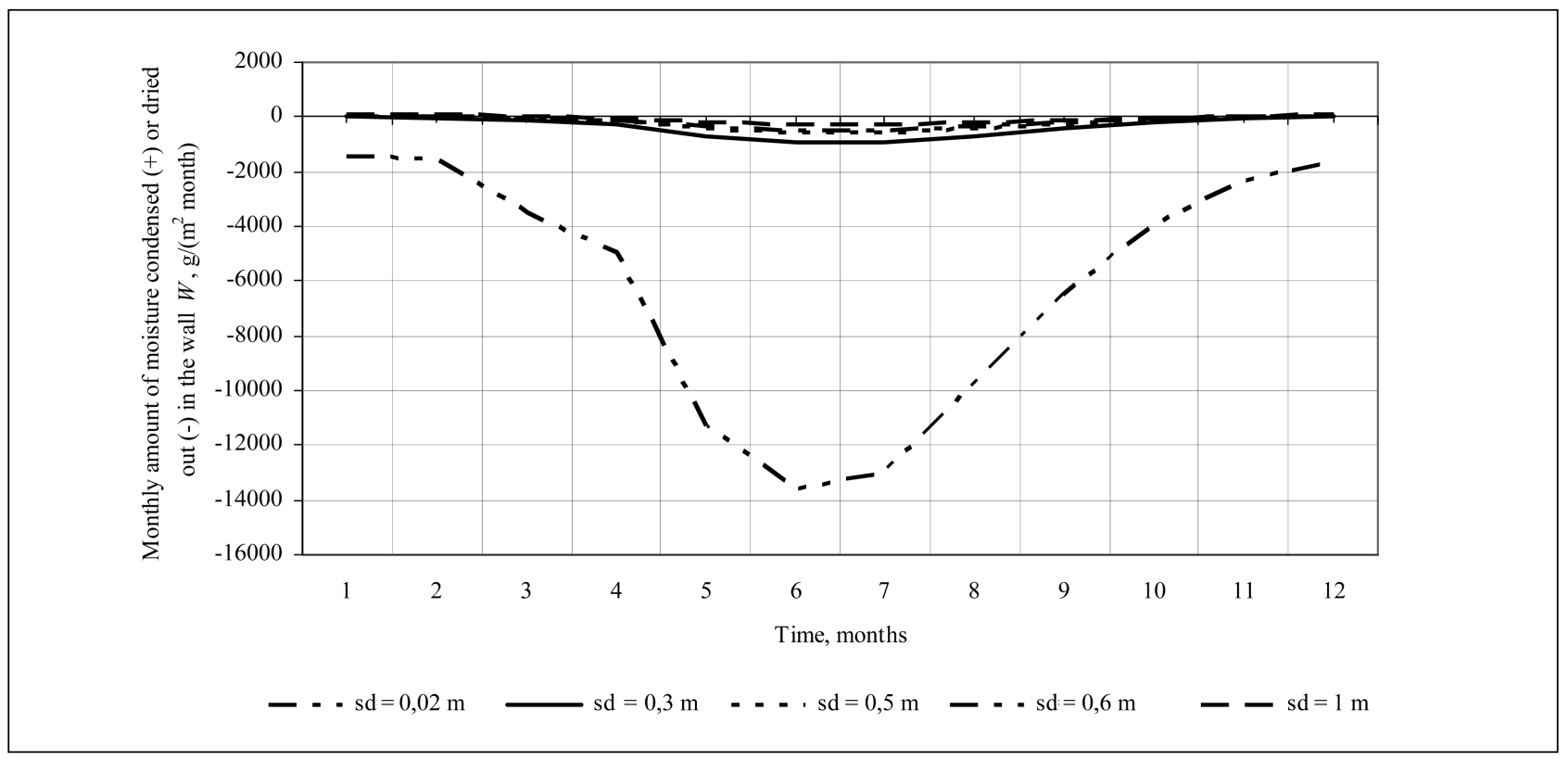

Fig 8. Annual dynamics of moisture alteration in the wall in its possible zone of condensation when the thickness of the air layer equivalent to the material's water vapour permeability $s_{d}$ varies 
and paint coating) demonstrates that, when in the paint coating the thickness $s_{d}$ of the air layer equivalent to the building material's water vapour permeability is higher than $0,6 \mathrm{~m}$, the moisture will accumulate in the envelope (Fig 8).

The results of the paint's water permeability determination show that, under service conditions, the acrylic paint creates the preconditions for the decreased moisture in the walls caused by water vapour diffusion and the condensation factors.

\section{Conclusions}

1. Under local climatic conditions, the $s_{d}$ value of the thin render layer in the walls of the buildings exploited in Lithuania should be $s_{d}<0,5 \mathrm{~m}$ and that of the paint coating should be $s_{d}<0,6 \mathrm{~m}$.

2. The increase of the $s_{d}$ value depends on the number of the paint layers, ie on the thickness of the entire paint coating.

3. The raise of the acrylic paint $s_{d}$ value creates the possibility for the increased moisture in the buildings when under service conditions which may be caused by water vapour diffusion and the condensation factors.

\section{References}

1. JANSSENS, A. and HENS, H. Condensation Risk Assessment. In Thermal Performance of the Exterior Envelope of Buildings. Florida, VII, Dec, 1998, p. 45-51.

2. SHALA, Y.; MAKHATKA, M. Thermoinsulation of the Building Facades (Теплоизоляция фасадов зданий на практике). Prague: Czech Republic. Obchodni, 2003, p. 18-60 (in Russian).

3. BARKAUSKAS, V.; STANKEVIČIUS, V. Thermal Physics of the Building Envelopes (Pastatų atitvaru šilumine fizika). Kaunas: Technologija, 1998. 325 p. (in Lithuanian).

4. MINIOTAITE, R.; STANKEVIČIUS, V. The Durability of Paints in Sand-lime Brick Walls Considering Water Sorption and Vapour Permeability in a Two-layer System. Journal of Civil Engineering and Management, 2003, Vol IX, No 2, p. $110-114$.

5. MINIOTAITE, R. Water Vapour Permeability and Sorption of Painted Substrates. In The $8^{\text {th }}$ International Conference "Modern Building Materials, Structures and Techniques", May 19-21, 2004, Vilnius: Technika, 2004, p. 109-113.
6. FOKIN, K. F. Constructional Thermotechnique of the Buildings (Строительная теплотехника ограждающих частей зданий). Moscow: Strojizdat, 1973. 287 p. (in Russian).

7. SHIELD, E. et al. Constructional Physics (Строительная физика). Moscow: Strojizdat, 1982 (in Russian).

8. LST EN 13500: 2004. Thermal Insulation Products for Buildings - External Thermal Insulation Composite Systems (ETICS) Based on Mineral Wool-Specification, 2002-10, p. 11.

9. DIN 18550 Teil 1. Putz. Begriffe und Anforderungen. 1985, p. 10.

10. RAADO, L. M. \& TUISK, T. Stability of Mineral Binding Based External Rendering Systems. In The ${ }^{\text {th }}$ International Conference "Modern Building Materials, Structures and Techniques ", May 19-21, 2004. Vilnius: Technika, 2004, p. 140 144.

11. EN ISO 13788. Hydrothermal Performance of Building Components and Building Elements - Internal Surface Temperature to Avoid Critical Surface Humidity and Interstitial Condensation - Calculation Methods. B-1050 Brussels, 2001, p. $1-20$.

12. STR 2.05.01:2005. Thermal Physics of the Building Envelopes (Pastatu atitvaru šiluminè technika). Vilnius, 2005, p. 100130 (in Lithuanian).

13. RSN 143-92. Thermal Physics of the Building Envelopes (Pastatų atitvarų šiluminè technika). Vilnius, 1992, p. 37-45 (in Lithuanian).

14. ASHTON, H. E. New Organic Coatings. CBD-79. Available from internet: $<$ http://irc.nrc-cnrc.gc.ca/cbd/cbd079e.html $>$.

15. ASHTON, H. E. Paint - What Is It? CBD-76. Available from internet: <http://irc.nrc-cnrc.gc.ca/cbd/cbd076e.html>.

16. MAYER, H. Silicone-resin Emulsion Paint for Perfect Facades. Tikkurila Coatings \& Paints Journal. Finland: Tikkurila Oy, 9-10/2003, p. 32-33.

17. LAMMINMAKI, S. Novasil Lets a Facade Breathe. Tikkurila Coatings \& Paints Journal. Finland: Tikkurila Oy, 3/1996, p. 33.

18. Paints, Renders, Varnish. "Tex Color” (Краски, штукатурки, лаки) (in Russian).

19. Wacker Silicone für Baufarben. Wacker Edition. München: Februar 1995.

20. LST EN ISO 12572:2001. Hydrothermal Performance of Building Materials and Products - Determination of Water Vapour Transmission Properties. Vilnius: Lietuvos standartizacijos departamentas, 2001, p. 5-20.

21. RAMANAUSKAS, J.; STANKEVIČIUS, V. Weather Durability of Thermal Insulation Systems in External Walls (Pastatu sienų šiltinimo sistemų atsparumas klimato poveikiams). Monograph. Kaunas: Technologija, 2000. 85 p. (in Lithuanian).

\section{IŠORINĖS APDAILOS GARINĖS VARŽOS İTAKA PASTATŲ SIENŲ DRĖGNUMUI}

\section{J. Šadauskienė, E. Monstvilas, V. Stankevičius}

Santrauka

Pastaruoju metu projektuojant iš išorès mineralinès vatos plokštėmis apšiltintas sienas su dažyto plonasluoksnio tinko apdaila, vis dažniau atsiranda defektų dèl atitvarose susikaupiančios kondensacinès drégmès. Išorinès apdailos (dažų) vandens garų laidumas, palyginti su mineralinės vatos plokštės vandens garų laidumu, yra mažas, todèl dažų sluoksnis gali tapti barjeru vandens garų difuzijai ir sudaryti prielaidas drègmei kauptis išoriniuose atitvaros sluoksniuose šaltuoju metų laiku. Bandant pašalinti atsiradusius defektus, 
paprastai išorės paviršius yra perdažomas, paliekant senų dažų sluoksni, nes tinkas yra plonas ir mechaniškai lengvai pažeidžiamas. Dẻl šios priežasties plonasluoksnio tinko paviršiaus perdažymas yra susijęs su: 1) paviršinio sluoksnio garinès varžos didinimu; 2) kondensacijos intensyvumo padidejimu išoriniuose atitvaros sluoksniuose drègmès kaupimo laikotarpiu; 3) sistemos tinku - dažais ilgaamžiškumui mažinti. Jau išorinio atitvaros sluoksnio $s_{d}$ apribojimai rekomenduojami taikyti Europos Sajungos valstybėse. Drègmę kauptis sienos viduje skatina vietovés klimatas, todèl reikia nustatyti, ar šios $s_{d}$ verčiu rekomendacijos tinka Lietuvoje eksploatuojamų pastatų sienų išoriniams sluoksniams. Tam buvo atlikti atitvaros drègminès būklès skaičiavimai ir laboratoriniai tyrimai. Šiame darbe išanalizuota išoriniu sienos sluoksnių garų laidumo savybių i taka atitvaros drègnumui. Nustatyta, kad šios $s_{d}$ vertès didèjimas neproporcingas dažų sluoksnių skaičiui ar dažų dangos storiui. Taip pat nustatyta, kad išorinių apdailos sluoksnių $s_{d}$ vertès didinimas sudaro prielaidas šiu sluoksnių padidintam drègniui eksploatacijos sąlygomis atsirasti dèl vandens garų difuzijos ir kondensacijos reiškinių. Atlikus tyrimus nustatyta, kad Lietuvos klimato sąlygomis eksploatuojamų pastatų sienų plonasluoksnio tinko sluoksnio $s_{d}$ vertè turi būti $s_{d}<0,5 \mathrm{~m}$, o dažų dangos $s_{d}<0,6 \mathrm{~m}$.

Reikšminiai žodžiai: dažytas plonasluoksnis tinkas, išorinio apšiltinimo sistemos, vandens garų laidumas, santykinẻ garinè sluoksnio varža, lygiavertis medžiagos vandens garų laidumui oro sluoksnio storis, drègnumas.

Jolanta ŠADAUSKIENĖ. Junior Researcher at the Laboratory of Thermal Building Physics at the Institute of Architecture and Construction, KTU.

Research interests: the impact of thin render and paint coating's vapour resistance to the moisture behaviour in the exterior finish of the building envelopes.

Edmundas MONSTVILAS. Doctor, Senior Researcher at the Laboratory of Thermal Building Physics at the Institute of Architecture and Construction, KTU.

Research interests: the moisture state of the building constructions; physical-technical processes in building envelopes; heat loss in buildings; energy utility of the buildings.

Vytautas STANKEVIČIUS. Doctor Habil, Professor, Chief Researcher at the Laboratory of Thermal Building Physics at the Institute of Architecture and Construction, KTU. Author of over 200 papers and 4 patents.

The main research areas include the physical properties of the building materials; physical-technical processes in the building envelopes; energy saving in buildings; weather durability of the external finish of the building walls. 